Journal of Literature, Linguistics, and Language Teaching

Volume 2 (1) 2021

ISSN: 2746-8968 (online)

https://journal.unesa.ac.id/index.php/nld/index

\title{
The Study of Native Surabaya Young People Refusal Strategy in English
}

\author{
Isro Datul Khasanah ${ }^{\mathrm{a}}$, Dwijani Ratnadewi ${ }^{\mathrm{b}}$, Sofi Yunianti ${ }^{\mathrm{c}^{*}}$ \\ ${ }^{a, b, c}$ Muhammadiyah University of Surabaya, Indonesia \\ *Corresponding Author: sofiyunianti@fkip.um-surabaya.ac.id.
}

\begin{abstract}
Refusal often ends in misunderstanding and even anger, so people organize and maintain their refusal to avoid face threats. The people of Surabaya use the native Surabaya language, which is known as an open and blunt language, so a rejection strategy is assumed similar to this characteristic. This thesis aims to analyze what types of refusal strategies of native Surabaya young people use and how they use them in English. It examines how respondents refused the invitation, request, offer, or suggestion in various situations. This is a qualitative study with 21 native Surabaya young people, the EFL learners completing a Written Discourse Completion Test or WDCT, which contains several scenarios based on power and social distance. Data were analyzed using SPSS and the results showed that although the respondents came from Surabaya, which is known for its outspoken speaking style, in fact only $12.6 \%$ of respondents used the direct refusal strategy, conversely, most respondents used indirect refusal strategy $(79.7 \%)$ in expressing their rejection, while the least used strategy was Adjunct (7.7\%). The respondents continued to use the indirect refusal strategies, even though they had more power and less closeness or have equal power and closeness to the interlocutors.
\end{abstract}

Keywords: Rejection Strategy, Social Variable, Surabaya native language

\section{INTRODUCTION}

There are several forms of conversation to avoid offending others, including refusal, where to refuse someone requires a certain strategy so that there is no misunderstanding, offense, and even anger. As Al-Kahtani (2005) states that refusal is a very crucial reaction in which requires a strategy so as not to hurt feelings, since refusal may be a face-threat to interlocutors (Iliadi \& Larina, 2017). This is because refusal is a negative reaction toward requests, invitations, suggestions, offers that are usually used in daily life (Sadler \& Eröz, 2002). Refusal is an expression to show that the speaker does not accept or agree with something. It can be direct and Indirect Refusal (Beebe, Takahashi, Uliss-Weltz, Scarcella, \& Andersen, 1990), the choice of the strategy depends on several aspects like social distance, power, and degree of imposition, which is based on the culture of the language-user community. Individuals from various cultures will utilize distinctive refusal techniques since each culture has a different route in ensuring a speaker positive face and diminishing the danger that occurs because of a refusal. Therefore, people have different ways to express their refusal strategies to cover their image and minimize harm.

The strategies preferred in conversation is culture specific, it depends on the society specific. It is a set of attributes that is the characteristics or reflections of how individuals relate to one another in a group. However, Brown and Levinson (1987) argue that the combination of social distance, power relations, and task imposition perceived the level of politeness regardless of the culture. Yet numerous variables may contribute to deciding the degree of 
Journal of Literature, Linguistics, and Language Teaching

Volume 2 (1) 2021

ISSN: 2746-8968 (online)

https://journal.unesa.ac.id/index.php/nld/index

social distance or closeness between individuals' relatives (age, sex, social jobs, regardless of whether individuals cooperate, or are individuals from a similar family, etc.). Social distance is known as a tool to measure the level of friendship/familiarity with the collocutor as Holmes (1992) categorizes social distance levels (Strangers - Friends - Intimates). Power is the addressee's position in society and age, the social status; the relative power of the hearer over the speaker, and vice versa. Situations in which some expect another person to do something that they do not want to do or that is not convenient. Moreover, the rank of impositions refers to the importance of the degree of difficulty in a situation. A big imposition will be seen if the interlocutor asks for a big favor from the other interlocutor, and a small imposition will be seen when the request is small. Based on Brown \& Levinson (1987), these three factors are viewed in various ways: $\mathrm{P}$ (Power) is assessed as being great because the interlocutor is fluent and influential, and D (Distance) is typically a measure of social distance between speaker and hearer. In this study, $\mathrm{P}$ and $\mathrm{D}$ were used, $\mathrm{P}$ as age and social status differences among the interlocutors, and $\mathrm{D}$ as differences in familiarity between the respondents.

Beebe et al. (1990) characterize refusal strategies in regards to the level of straightforwardness. The strategies are divided into two, they are direct and indirect refusal. The direct technique is the clearest system in utilizing demand. This uses to enforce the power of somebody's demand, recommend, invite and offer. The speakers plainly state what their craving or need in their locution, so it is extremely clear for the audience to do what the speaker's plan. The indirect technique is the system in utilizing demand. It is used to impose one's strengths, solicit, recommend, invite and offer politely. Speakers can utilize other styles when they refuse; it is called an adjunct. Adjunct strategy implies that people deny others' solicitation by adding something or connecting it to something bigger or progressively noteworthy. It may be utilized by using positive feeling explanations like 'That is a smart thought; compassion proclamation 'I know you're in an awful circumstance'; fillers like 'ah' and 'uhm'; gratefulness/thankfulness like 'bless your heart'.

Several studies on refusal illustrate that the choice to use Indirect, Direct or Adjunct Refusal is influenced by various aspects. For example, one's status and knowledge of language greatly influence the choice of refusal strategy, as stated by Tuncer (2016), as instructors in the English Department and having good knowledge of English made these participants mostly used Indirect Refusal Strategy. Zivkoviks (2020) found that the refusal strategy shown by the British and Serbs tended to use the Indirect strategy, but the British tended to use the Adjunct refusal while the Serbs, more sensitive to status, used the direct rejection of the subordinate interlocutor more than the parallel interlocutor or higher power. German Native Speakers preferred slightly more direct strategies compared to Malay Native Speakers but this differed based on the situation is formal or not. Malay respondents tended to use statements of regret in their refusal strategy more frequently than German native speakers did. Malay speakers also commonly used religious terms in their refusal strategy (Jalis, Abdul Jabar, Halim, \& Bukhardt, 2019). Mitkova (2018) investigated the refusal strategies used in the Business English Setting by Native English. The result shows that the respondents were mostly using reason/explanation, regret/apology, and statements of facts to express their indirect strategy and they used willingness and gratitude for the Adjunct part.

In Java, Indonesia, the refusal of a word like 'No' is deemed to offend others. The Javanese language applies patterns including refusal. Most of them use words as if they do not reject something and they try to avoid the word 'No'. They will use words or other means of expressing their refusals such as providing reasons to avoid conflict between speaker and listener. Therefore, indirect statements are commonly used (Endraswara, 2010). Although Surabaya is one of the regions in Java, it has certain characteristics to differentiate it from other 
Journal of Literature, Linguistics, and Language Teaching

Volume 2 (1) 2021

ISSN: 2746-8968 (online)

https://journal.unesa.ac.id/index.php/nld/index

regions (Ardelawati, 2014). One of the characteristics is the language used in communication. The Javanese Surabaya language is a Javanese dialect with more egalitarian and outspoken characteristics (Miladi,2020). Javanese language used by the people of Surabaya is not the same as the standard Javanese used in Solo and Yogyakarta. The level of Javanese language: low, equal, high (Ngoko, Krama Madya, Krama Inggil) is slightly different from that of the original Javanese. According to (Setiawan, 2013) the Javanese dialect between Surabaya (East Java) and Surakarta (Central Java) are different caused of some aspects: like intonation, pronunciation, word form, and word meaning. The language used by the people of Surabaya is a bit rough but gives the impression of kinship (Trijanto, 2012) and egalitarian. This is due to the location of the city of Surabaya, which is far from the Javanese cultural center or the palace environment. The language has a function to unite the culture in Surabaya itself since many ethnicities live in Surabaya (Dedayev, 2017). The language, which is egalitarian and friendly, is easily understood in all levels of Surabaya society in interaction. This research aims at discovering the kind and the way refusal strategies are implemented in English conversation among young native Surabaya.

\section{METHOD}

This is descriptive qualitative design research, it uses special procedures for getting the information, analyses the fabric over numerous steps of the study, and mentions approaches to write down the accuracy of the collected data (Creswell, 2013). Qualitative work is an attempt to address the logical, behavioral, perceptual, and individual dimensions of the social aspect (Saddiyah \& Rokhman, 2018). Therefore, researchers uncovered phenomena about the native Surabaya young people's refusal strategy to make it easier to understand and consider. This research was conducted in Surabaya in 2020. The subjects of this research were 21 EFL learners from some Universities in Surabaya. They were native Surabaya young people. The samples were selected by filling out Demographic questions to these students. WDCT or Written Discourse Completion Test (Parvaresh \& Tavakoli, 2009) was used to obtain the data, with contextually 6 specifics prompts/situations based on Brown and Levinson (1987) social variables, where $\mathrm{P}$ (power) and $\mathrm{D}$ (social distance) under the fundamental situations in various functions, they are Refusal of request, offer, invitation, and suggestion. The data taken from WDCT were categorized into the kinds of refusal strategies. The frequency of the kinds of refusal strategy observed using SPSS application. The kinds of indirect strategies were categorized based on Beebe et al.'s (1990) 11 semantic formulas in the indirect refusal strategy.

\section{FINDINGS AND DISCUSSION}

Refusal strategies among native Surabaya young people were found different from the statement of Dedayev (Dedayev, 2017) saying that Surabaya's native language is firmer and more straightforward. In addition, it is also beyond the expectation that native Surabaya young people are known to have an open, firm, and straightforward attitude in speaking (Miladi, 2020) were found to perform the refusal strategy indirectly. Mostly Indirect refusal was found beside some other kinds of strategies. This study also calculated the frequency of kinds of strategies in their English respond. As seen in Table 1 the total number of frequencies used was 231 taken from 21 respondents, each gave 11 responses to the situation in WDCT. 
Journal of Literature, Linguistics, and Language Teaching

Volume 2 (1) 2021

ISSN: 2746-8968 (online)

https://journal.unesa.ac.id/index.php/nld/index

TABLE 1. Kinds of Refusal Strategies

\begin{tabular}{ccc}
\hline $\begin{array}{c}\text { Kinds of Refusal } \\
\text { Strategy }\end{array}$ & Frequency & Percentage \\
\hline Indirect & 184 & 79.7 \\
Direct & 29 & 12.6 \\
Adjunct & 18 & 7.7 \\
Total & 231 & 100.0 \\
\hline
\end{tabular}

The type of strategy that was found the most was the indirect strategy with the frequency of $184(79.7 \%)$, the second most used refusal strategy was indirect $(12.6 \%)$ and the least strategy was $18(7.7 \%)$.

\section{INDIRECT STRATEGIES}

Of the 231 refusal strategies found $79.7 \%$ were in the form of Indirect and this strategy was expressed in different ways. This finding is following the opinion of Felix-Brasdefer (2008) that the indirect refusal is uttered using the right pattern so that the interlocutor does not feel offended by the rejection statement expressed. This finding is seen in Table 2.

TABLE 2: Kinds of Indirect Strategies

\begin{tabular}{lcc}
\hline \multicolumn{1}{c}{ Semantic Formula of Indirect Strategies } & Frequency & Percent \\
\hline Statement of regret/apology & 74 & 40.2 \\
Excuse, reason, and explanation & 54 & 29.3 \\
Let interlocutor off the hook & 21 & 11.4 \\
Promise of future acceptance & 12 & 6.5 \\
Statement of negative feeling or opinion; & 8 & 4.3 \\
insult/attack & 5 & 2.7 \\
Statement of principle & 3 & 1.6 \\
Postponement & 2 & 1.1 \\
Can do X instead of Y & 1 & .5 \\
Wish & 1 & .5 \\
Self defence & 1 & .5 \\
Repetition & & \\
Request for help, empathy, and assistance by dropping & 1 & .5 \\
or holding the request & 1 & .5 \\
Hesitation & 184 & 100.0 \\
Total & & \\
\hline
\end{tabular}

The table describes the various semantic formulas of the Indirect Refusal as expressed by respondents. The highest frequencies are found in regret/apology $(40.2 \%)$, the secondhighest is excuse, reason, and explanation $(29.3 \%)$, and the third is in 'let interlocutor off the hook' $(11.4 \%)$. The respondents use the indirect refusal strategy using a promise for future action $(6.5 \%)$, but the statements of negative feeling or opinion; insult/attack are also found $(4,3 \%)$.

Saying regret/apology is the most frequent strategies used by the respondents to refuse. Most of the respondents apologized when they could not fulfill the interlocutor request/offer/ suggestion/invitation. Some respondents added some statements after they said sorry, such as 'Sorry, I'm visioner and love this earth'. Interviews were conducted with the respondents and the reason they chose these refusal strategies was to avoid negative impressions or appear to 
Journal of Literature, Linguistics, and Language Teaching

Volume 2 (1) 2021

ISSN: 2746-8968 (online)

https://journal.unesa.ac.id/index.php/nld/index

offend the speaker and aim to end the conversation immediately between respondents and the interlocutor. The second most used indirect strategy was 'Excuse, reason, and explanation'. The respondents did not give specific responses as answers nor provide direct responses needed but rather they gave reasons and explanations as a rejection. As an example, the respondent did refusal an invitation by a close friend to go to the coffee shop together by stating 'Friend, I must buy the medicine for my hero'. Here the respondent refused the offer using an indirect refusal strategy for a concise and clear reason, so the interlocutor must conclude himself that he declined the invitation. 'Let interlocutor off the hook' is the third most frequently used indirect strategy. This strategy is a strategy in which the respondent tries to reject what the other person is asking or offering by trying to keep calm and not offended when the respondent cannot fulfill what the other person needs/ask. Usually, to avoid the impolite or negative impression, the respondent will provide several alternatives or suggestions after receiving a rejection. As the following statement, a lecturer suggested he use stairs than elevator because at that moment the elevator was so crowded, he refused by saying 'No problem ma'am because I still have a long time to go'.

\section{DIRECT STRATEGIES}

The direct strategy is the second strategy frequently used by the respondents in this research. Direct rejection of invitations, offers, suggestions from others against respondents is found like Retnowaty's (2018) opinion which sometimes appears to be 'clear' utterance using nonperformatives like 'no' and negative willingness/ability like 'I can't!' 'I won't', 'I don't think so,' also performative verbs like 'I refuse'. This strategy appears 29 times (12.6\%) from the whole strategy. The following are the kinds of direct strategies found.

TABLE 3: Kinds of Direct Strategies

\begin{tabular}{lcc}
\hline $\begin{array}{l}\text { Semantic Formula of Indirect } \\
\text { Strategies }\end{array}$ & Frequency & $\begin{array}{c}\text { Percentag } \\
\mathrm{e}\end{array}$ \\
\hline Negative Willingness/Ability & 15 & 51.7 \\
Non-Performative (No) & 9 & 31.0 \\
Performative & 5 & 17.2 \\
Total & 29 & 100.0 \\
\hline
\end{tabular}

Table 3 illustrates the different kinds of direct refusal strategies. The negative Willingness/ Ability strategy is the most frequently used direct strategy; it reaches $51.7 \%$ of all the direct strategies. The speaker used negative willingness to make them easier to end the conversation and left the interlocutor without feeling guilty. As in the utterance, 'I can't give you my number, sorry'. The second most frequently used direct strategy is the nonperformative strategy reaches $31.0 \%$. Sometimes the speaker mixed Non-Performative with others to refuse (Beebe et al. 1990) in this research, the respondents mixed Non-Performative with gratitude/appreciation or give explanations like the following example: 'No, thanks'. 'No need, it's only a crack on the screen and the function still work. So no need the new one'. 
Journal of Literature, Linguistics, and Language Teaching

Volume 2 (1) 2021

ISSN: 2746-8968 (online)

https://journal.unesa.ac.id/index.php/nld/index

\section{ADJUNCT STRATEGIES}

Adjuncts in refusal found were those strategies that were added or connected to statements like positive opinion, for example 'I would love to'; statement of empathy 'I know you are in a bad situation'; pause fillers like 'uhh' and 'well'; gratitude/appreciation like 'Thank you so much.'.

\begin{tabular}{lcc}
\multicolumn{3}{c}{ TABLE 4: Kinds of Adjunct Strategies } \\
\hline Semantic Formula of Indirect Strategies & Frequency & Percentage \\
\hline $\begin{array}{l}\text { Gratitude/appreciation } \\
\begin{array}{l}\text { Statement of positive opinions/ } \\
\text { feeling of agreement }\end{array}\end{array}$ & 13 & 72.2 \\
Total & 5 & 27.8 \\
\hline
\end{tabular}

As seen in Table 4, there are two kinds of adjunct strategies used by the respondent when they refused the interlocutor. The first is gratitude/appreciation; they used the strategy 13 times while using the statement of positive opinions/feeling of agreement 5 times or $27.8 \%$. To avoid negative impressions and offending the other party when they made a refusal, the respondents gave appreciation/gratitude as the refusal. A short explanation was also found to follow appreciation or gratitude. As seen in the utterance of 'Thanks, but I enjoy it.', 'Thank you, ma'am, but I have a meeting schedule today'.

\section{REFUSAL STRATEGIES BASED ON POWER AND SOCIAL DISTANCE}

Although most of the respondents used the indirect refusal strategy, some of them still reflected the culture of the people of Surabaya, which is famous for its straightforward and assertive. This follows what Dedayev (2017) has stated that Surabaya's native language is considered unique in its use especially because of its open, direct, and straightforward language. They used indirect refusal strategies, but in delivering it, they tried to be honest with their inability to fulfill the suggestions, requests, and offers given by the interlocutors.

As seen in the DCT the situation of $(=\mathrm{P} /=\mathrm{D})$ or equal power and close distance, most of the respondents use the indirect refusal to refuse the suggestion from her/his best friends.

1. 'I'm sorry I can't' or

2. 'Thanks, but I enjoy it.'.

In these situations, indirect strategies in refusing were preferred by the respondents having an equal status relationship. The hint of refusal in (1), the speaker would like to minimize the discomfort on the part of the addresser and the disappointment on the part of the addressee. Likewise, the utterance in (2) Adjunct strategy was used. The hint of refusal in (2) is recognizable that the respondent was not interested in the suggestion and he chose the utterance to appreciate the suggestions given by his best friend. An apology is a redressive articulation where a speaker says that he/she is upset for rejecting something. Using this strategy, an addresser would like to show that she/he does not intend to hurt his/her addressee's feelings.

In the second situation of $-\mathrm{P} /=\mathrm{D}$ or less power and close distance, the respondents used indirect refusal strategies, even though they had a chance to use direct refusal because they were in the position of higher power and close relationship to the interlocutor.

3. 'Keep calm, sist. I can do myself'

4. 'Will you buy the new one for me?' 
Journal of Literature, Linguistics, and Language Teaching

Volume 2 (1) 2021

ISSN: 2746-8968 (online)

https://journal.unesa.ac.id/index.php/nld/index

In (3) the respondent used the utterance to present the disagreement of the suggestions. She did not want to prolong the problem. While, in (4), the respondent showed his disagreement with the interlocutor's suggestion by stating a question to the interlocutor that may function as a joke. This aims to give a piece of information to the interlocutor that he did not agree with the idea.

In the situation of $(+\mathrm{P} /=\mathrm{D})$ where the interlocutor was with higher power but close relation, the Indirect refusal strategy and reason added were mostly used by the respondents.

(4) 'I do apologize, sir, I want to join with you but I must print these assignments'.

(5) "Thank $\mathrm{u}$ for your invitation mam, but I have to do something before class. I will join next time."

(6) 'That good idea, but I have something to do. Enjoy your meal'.

Presenting other priorities or agendas is another semantic formula that commonly occurred in refusal. A refuser mentioned a more urgent agenda in this indirect refusal strategy. From the utterance in (4), the respondent said that he could not accept the invitation because he had to finish his assignment for the next class. In (5) the respondent also used indirect refusal strategy by explaining the existence of the other agenda. The difference with the (4) has they used a different kind of opening, the first is a statement of apology and the latter is an appreciation. In (6), the Adjunct strategy was used in this utterance. The respondent delivered his opinion about the invitation by stating a positive opinion through the invitation, but it was followed with the explanation and greeting signing a refusal to accompany and join with his lecturer.

In the situation $(+\mathrm{P} /+\mathrm{D})$ with the interlocutor's power is higher and the social distance is not close, the refusal is seen using more formal and indirect.

(7) 'Sorry Mr..., can we discuss it again?'.

(8) 'Sorry mam/sir but I have done a preliminary study of the research, I beg to check again. But if you think changing the title of the thesis is the best for my thesis I will do it.'.

From the utterance (7), the respondent asked the interlocutor to discuss the title, it is indicated that the speaker had a desire to refuse the request indirectly. He would like to minimize the discomfort on the part of the addresser and the disappointment on the part of the addressee. The respondent in (8) refused his lecturer's suggestion followed by his reason about the preliminary study of the research he had done. He tried to ask the consideration from the lecturer. The respondent tried to refuse the request by apologizing to minimize the negative effect and using formal language accompanying the refusal since he was talking to the lecturer and was not very close to him. The differences in power and distance made the respondent chose this kind of strategy.

In the situation of $(+\mathrm{P} /-\mathrm{D})$ where the interlocutor has higher power but close relation to the respondent, the indirect refusal was maintained. Yet, the strategy was conveyed firmly and straightforwardly.

(10) 'I have a meeting schedule, aunt. Next time I will stay here.'

(11) 'Thanks in advance but I must attend some meetings.'

In (10) the respondent used an indirect refusal strategy but the respondent expressed the reason directly for the inability of the respondent to accept the offer given and to reduce the negative impression on the older interlocutor, the respondent added with a promise to stay next time. It was meant to reduce negative impressions and appreciate the offer that has been made for him. 
Journal of Literature, Linguistics, and Language Teaching

Volume 2 (1) 2021

ISSN: 2746-8968 (online)

https://journal.unesa.ac.id/index.php/nld/index

In (11) adjunct indirect refusal strategy was used and added with a reason, but still tried to be polite in front of his interlocutor who had more power than the respondent.

\section{FINDINGS AND DISCUSSION}

The finding shows that the respondents preferred to use indirect refusal strategy to deliver their inability to receive or accept requests, offers, invitations, and suggestions from the interlocutors. This finding in line with a previous study by Wardani (2019) stated that the frequently used refusal strategy is indirect refusal. This is also in line with (Azis, 2000), who states that indirectness is best considered regarded as the speaker's wisdom, which seems to control under the Tact Maxim of Leech's politeness principle. With the reason that if the respondent states his refusal without realizing the position of the interlocutor, it will affect the relationship between the interlocutors. Therefore, the interlocutor must consider choosing what and how to convey his rejection. Accommodating the indirect refusal, the interlocutor understands the other's reasons why they should reject it. In addition, indirect rejection also avoids the face threat, and therefore conflict may be avoided.

The way of respondents delivered the statement of apology/regret in their refusal is to reflect the influence of the culture in which they are brought up to respect others. As one of the Javanese dialects, the native Surabaya language still uses Javanese rules, where communication in Javanese culture is managed through politeness stages. This fact is not in line with Farnia \&Abdul Sattar (2015) that the non-local speakers as the respondents are not as explicit and straightforward as local speakers. This research respondents were native Surabaya speakers, yet they were not straightforward in their refusal.

This finding confirms but also does not go with the theory of Brown and Levinson (1987) which states that whatever the culture, what influences the choice of speech according to the circumstances is $\mathrm{P}$ (power), $\mathrm{D}$ (distance), because it turns out that for most respondents, whatever the social diversity is, it turns out that they chose to use Indirect Refusal. Culture may most likely be the reason. This is contrary to the previous expectations, that if they were faced with a situation where they had equal social distance and power they would prefer to use the strategy of outright resistance. However, it turns out that the indirect refusal strategy was mostly chosen. Some short sentences but considered polite to avoid the negative actions were found afterward. For example, when the respondent had just gotten off from public transportation, a close friend suggested he drive his private vehicle, most respondents used short, concise, and clear indirect refusal utterances.

Meanwhile, when they were dealing with interlocutors with lower social distance and power, they sometimes used sentences in the form of satire at informing the other party that it is not appropriate to give statements or speak like that, especially when the interlocutor talked about personal matters. For example, where a friend of the respondent's relative suggested that the respondent should replace his damaged cellphone. This might not be ethical enough to say by the interlocutor who somehow was less senior, but still, indirect rejection was used, in the form of satire. Yet, long and polite sentences appeared to accompany the Indirect Refusal towards interlocutor with far social distance and more power. They provided reasons and explanations that they thought would reduce the negative effects that might arise. In a situation like this, there might be a high imposition between the respondent and the lecturer as the interlocutor. This is because the demands imposed by the interlocutor to the respondent were very big and difficult, besides that there was also a far social distance and higher power causing the respondent to continue to show politeness in refusing. 
Journal of Literature, Linguistics, and Language Teaching

Volume 2 (1) 2021

ISSN: 2746-8968 (online)

https://journal.unesa.ac.id/index.php/nld/index

\section{CONCLUSION}

This thesis evaluates the refusal strategies used by native Surabaya young people, the ELT learners of some universities in Surabaya. After analyzing the data, several conclusions are found to answer the research questions. For refusal strategies, the researcher used the theory of refusal strategies based on Beebe et al. (1990). The theory provides three types of refusal strategies such as direct strategies, indirect strategies, and adjuncts. The result shows that the respondents applied almost all types of refusal strategies, although the indirect refusal strategy is the most frequently used. They appeared in the DCT 184 times, the second most frequently used was direct strategies appeared 29 times and adjuncts that appeared 18 times. The result from the previous explanation shows that respondents mostly used indirect strategy than direct strategy or adjunct even though culturally they came from a straightforward speaking society.

Social variables (Power and Social distance) have an influence on respondents when they delivered refusal, especially when the respondents had to refuse the interlocutor who had more power and high social distance. They delivered the refusal with a long explanation and reason to minimize the negative effect. Whereas, with the respondents who had more power but close distance, the respondents still used indirect strategy to refuse the suggestion, invitation, request, and offer from the interlocutor, but when they delivered the refusal it was short and clear. They used the indirect refusal strategy but always tried to give an honest reason that they could not fulfill the interlocutors' wishes.

\section{REFERENCES}

Al-Kahtani, S. A. (2005). Refusals Realizations in Three Different Cultures: ASpeech Act Theoretically-based Cross-cultural study. Journal of KingSaud University.

Ardelawati, E. (2014). Bentuk dan Makna Sumpah Serapah Masyarakat Jawa Dikota Surabaya. Surabaya: Universitas Airlangga Surabaya.

Azis, E. A. (2000). Refusing in Indonesian: Strategies and Politeness Implication. Monash: Monash University. Ph.D. Dissertation.

Beebe, L. M., Takahashi, T., Uliss-Weltz, R., Scarcella, R. C., \& Andersen, E. S.(1990). Pragmatic transfer in ESL refusals. Developing communicative competence in a second language., 55-73.

Brown, P., \& Levinson, S. C. (1987). Politeness: Some language Universals in Language used. Cambridge University Press.

Creswell, J. W. (2013). Research Design: Qualitative, Quantitative, and Mixed Method Approaches. USA: SAGE Publication.

Dedayev, T. (2017). Bahasa Suroboyoaan Dalam Analisis Sosiolinguistik (Karakteristik Bahasa Suroboyoan Dalam Perpektif Sosiolinguistik). Surabaya: Universitas Airlangga Surabaya.

Endraswara, S. (2010). Etika Hidup Orang Jawa: Pedoman Beretiket Dalam Menjalani Kehidupan Sehari-hari. Yogyakarta: Narasi.

Farnia, M \& Abdul Sattar, H.Q. (2015). A Cross-Cultural Study of Iranians' and Malays' Expressions of Gratitude. Journal of Intercultural Communication. Issue 37, March 2015

Félix-Brasdefer, J. C. (2008). Politeness in Mexico and the United States: AContrastive Study of the realization and perception of refusals. JohnBenjamins Publishing Company.

Holmes, J. (1992). An Introductions to Sociolinguistics. London: Longman.

Iliadi, P.-L., \& Larina, T. V. (2017). Refusal Strategies in English and Russian. RUDN Journal of Language Studies, Semiotics and Semantics, 531-542. 


\section{New Language Dimensions}

Journal of Literature, Linguistics, and Language Teaching

Volume 2 (1) 2021

ISSN: 2746-8968 (online)

https://journal.unesa.ac.id/index.php/nld/index

Jalis, F., Abdul Jabar, M. A., Halim, H. A., \& Bukhardt, J. M. (2019). Refusal Strategy Used by Malay and German Native Speakers to Refuse Request.Asian Social Science; Vol. 15, No. 4, 49 - 59.

Mitkova, P. (2018). Refusal Strategies In Business Communication of NativeEnglish Speakers. Knowledge-International Journal, 1451-1456.

Miladi, I. (2020). Bila Ingin Berkata Kasar, Belajarlah Bahasa Surabaya. Kompasiana.https://www.kompasiana.com/primata/5f4e7de1d541df3aed287f83/bi la-ingin-berkata-kasar-belajarlah-bahasa-surabaya

Parvaresh, V., \& Tavakoli, M. (2009). Discourse Completion Test as ElicitationTools: How Convergent Are They? The Social Sciences 4. Medwell Journals, 366-373.

Retnowaty. (2018). Refusal Strategies by Javanese Teachers in Balikpapan. RETORIKA: Jurnal Ilmu Bahasa, Vol. 4, 10-16.

Saddiyah, C., \& Rokhman, F. (2018). Diglossia of Javanese-Indonesia in SeniorHigh School Educational Domain: Sociolinguistics Study in Tegal Regency. Seloka; Jurnal Pendidikan Bahasa dan Sastra Indonesia, Universitas Negeri Semarang, 9 - 17.

Sadler, R. W., \& Eröz, B. (n.d.). (2002).'I Refuse You!' An Examination of EnglishRefusals By Native Speakers of English, Lao, and Turkish. Arizona Working Papers in SLAT, $53-80$.

Setiawan, S. (2013). Children's Language in Bilingual Community in East Java. Perth: University of Western Australia.

Trijanto, E. K. (2012). Bahasa Jawa Dialek Surabaya, Warisan jati diri masa lalu,kini, dan kelak. Mabasan, 31-48.

Tuncer, H. (2016). Refusal Strategies Used by Turkish University Instructors of English. Novitas-ROYAL (Research on Youth and Language), 10(1), 71-90.

Wardani, F. D. (2019). Refusal Strategy Used by 5TH Semester Students of English Department in State Islamic University of Sunan Ampel Surabaya. Surabaya: State Islamic University of Sunan Ampel Surabaya.

Živković, E. (2020) Variation in refusal strategies produced by English and Serbian speakers, Studia Neophilologica, DOI: 10.1080/00393274.2020.1780939 